\title{
HUBUNGAN PENGETAHUAN DAN PERILAKU DENGAN TINGKAT KECEMASAN REMAJA TERHADAP COVID-19 PADA SISWA DI PESANTREN PANCASILA KOTA BENGKULU
}

\section{Relationship of knowledge and behavior with adolescent anxiety against covid-19 in students in Pesantren Pancasila Bengkulu City}

\author{
Syami Yulianti ${ }^{1}$, Lezi Yovita Sari ${ }^{2}$ \\ 1. Universitas Dehasen Bengkulu
}

\section{Riwayat artikel}

Diajukan: September 2020

Diterima: Maret 2021.

\section{PenulisKorespondensi: \\ - Syami Yulianti \\ - Universitas Dehasen Bengkulu \\ - Syamiyulianti@gmail.c $\underline{\text { om }}$}

\author{
Kata Kunci: \\ Covid-19, kecemasan, \\ pengetahuan, perilaku
}

\begin{abstract}
Abstrak
Pandemic Covid-19 merupakan fenomena yang menyita perhatian seluruh dunia di semua kalangan lapisan masyarakat. Pandemik ini sangat meresahkan dan menimbulkan ketakutan pada masyarakat luas secara global dan terkecuali masyarakat Indonesia. Jenis penelitian ini adalah analitik correlation dengan rancangan cross sectional. Populasi peneletian ini adalah semua siswa di Pondok Pesantren Pancasila Kota Bengkulu. Sampel penelitian sejumlah 32 orang diambil secara proportional random sampling. Variabel independent adalah pengetahuan dan perilaku remaja terhadap covid-19 dan variable dependent adalah tingkat kecemaan remaja terhadap covid-19. Instrumen penelitian menggunakan kuesioner. Pengolahan data menggunakan editing, coding, scoring, tabulating dan uji statistik menggunakan uji Chi square.

Berdasarkan analisis dan pembahasan maka penelitian ini menyimpulkan bahwa: sebagian besar remaja $(62,5 \%)$ di Pesantren Pancasila memiliki pengetahuan cukup tentang Covid-19, sebagian besar remaja $(53,1 \%)$ di Pesantren Pancasila memiliki perilaku positif tentang Covid-19, sebagian kecil remaja (15,6\%) di Pesantren Pancasila memiliki tingkat kecemasan berat tentang Covid-19 dan ada hubungan pengetahuan dan perilaku remaja terhadap Covid-19 dengan tingkat kecemasan pada siswa di Pesantren Pancasila Kota Bengkulu. Saran agar dapat lebih memberikan informasi mengenai wabah covid yang sedang terjadi, sehingga siswa bisa lebih siap dalam memasuki era new normal mendatang. Selain itu dapat memberikan layanan konseling agar tingkat kecemasan pada remaja dapat diperkecil. Layanan pada remaja untuk menurunkan kecemasan dalam masa oandemik covid-19 adalah layanan konseling individual, bimbingan dan konselong kelompok.
\end{abstract}

Abstract
The Covid-19 pandemic is a phenomenon that has captured the attention of the whole world at all levels of society. This pandemic is very disturbing and creates fear in the wider community globally and with the exception of the Indonesian people.

This type of research is analytical correlation with cross sectional design. The population of this research is all students at the Pancasila Islamic Boarding School, Bengkulu City. The research sample of 32 people was taken by proportional random sampling. The independent variable is the knowledge and behavior of adolescents towards Covid-19 and the dependent variable is the level of adolescence with regard to Covid-19. The research instrument used a questionnaire. Data processing used editing, coding, scoring, tabulating and statistical tests using the Chi square test.

Based on the analysis and discussion, this research concludes that: most of the youth $(62.5 \%)$ in the Pancasila Islamic Boarding School have sufficient knowledge about Covid-19, most of the youth $(53.1 \%)$ at the Pancasila Islamic Boarding School have positive attitudes about Covid-19, A small proportion of adolescents $(15.6 \%)$ in Pancasila Islamic Boarding Schools have a severe level of anxiety about Covid-19 and there is a relationship between knowledge and behavior of adolescents towards Covid19 with anxiety levels in students at the Pancasila Islamic Boarding School, Bengkulu City. Suggestions are to provide more information about the ongoing covid outbreak, so that students can be better prepared to enter the upcoming new normal era. In addition, it can provide counseling services so that the level of anxiety in adolescents can be reduced. Services for adolescents to reduce anxiety during the COVID-19 pandemic are individual counseling services, group guidance and counseling. 


\section{Pendahuluan}

Pandemic Covid-19 merupakan fenomena yang menyita perhatian seluruh dunia di semua kalangan lapisan masyarakat. Pandemik ini sangat meresahkan dan menimbulkan ketakutan pada masyarakat luas secara global dan terkecuali masyarakat Indonesia. Salah satu yang menyebabkan keresahan dan ketakutan di dalam masyarakat adalah penyebarannya yang sangat massif dan sangat cepat. Sejak ditemukan pada akhir bulan Desember 2019 di Wuhan Cina. Sejak Covid-19 pertama kali ditemukan, grafik jumlah kasus yang terinfeksi dan yang meninggal terus meningkat. Virus ini menular dengan cepat secara global termasuk Indonesia sendiri (Worldometers, 2020; Mosa-Baha, 2020).

Gejala Covid-19 dapat berupa gejala flu, yaitu demam, pilek, batuk kering, sakit tenggorokan, dan sakit kepala. Gejala ini dapat hilang atau sembuh namun dapat berkembang kepada keadaan yang lebih parah. Pada penderita dengan gejala yang parah dapat muncul demam tinggi, batuk berdahak bahkan berdarah. Bisa juga mengalami sesak nafas dan juga nyeri dada. Gejala-gejala ini merupakan akibat reaksi tubuh melawan virus ini. Secara umum, ada 3 gejala umum yang bisa menandakan seseorang terinfeksi virus covid-19 yaitu demam di atas 38 derajat celsius, batuk kering, sesak napas, ada beberapa gejala lain yang juga bisa muncul pada infeksi virus corona meskipun lebih jarang seperti diare, sakit kepala, konjungtivitis, hilangnya kemampuan mengecap rasa atau mencium bau, ruam di kulit. Munculnya gejala dapat terlihat dalam kurun waktu 2 hari sampai 2 minggu setelah penderita terpapar virus Covid-19 (Satgas penanganan Covid19, 2020; WHO, 2020).

Untuk saat ini belum disebutkan ada obat yang dapat secara efektif mengobati atau mengatasi Covid-19 ini. Pengobatan yang dilakukan hanya berdasarkan keluhan pasien dan tingkat keparahannya. Untuk penderita yang hanya mengalami gejala ringan akan dianjurkan melakukan isolasi secara mandiri di rumah dengan memantau gejala dan mengikuti protocol nasional untuk isolasi mandiri. Bagi yang mengalami gejala berat maka sebaiknya meminta pertolongan teaga kesehatan atau diisolasi dan ditangani di rumah sakit (WHO, 2020; Pratiwi, Yuniar, Bahana, \& Padmasawitri, 2020).

Selain stay at home masyarakat juga dianjurkan untuk melakukan tindakantindakan pencegahan seperti: membersihkan tangan secara teratur dan menyeluruh dengan antiseptik berbasis alkohol atau cuci dengan sabun dan air. Hal berikutnya adalah pertahankan jarak setidaknya 1 meter (3 kaki) sehingga ketika seseorang batuk, bersin, atau berbicara, mereka menyemprotkan tetesan cairan kecil dari hidung atau mulut yang mungkin mengandung virus. Diharapkan setiap orang menghindari pergi ke tempat keramaian. Hindari menyentuh mata, hidung dan mulut karena tangan menyentuh banyak permukaan dan bisa terkena virus. Hal yang sangat penting juga adalah memastikan kebersihan pernapasan yang baik. Ini berarti menutupi mulut dan hidung dengan siku atau tisu saat batuk atau bersin, dengan mengikuti kebersihan pernapasan yang baik, itu artinya melindungi orang-orang di sekitar kita dari virus Covid-19 (Kemkes, 2020; Mossa-Bassa, 2020; Yanti, 2020; Yuliana, 2020, Yunus \& Rezki, 2020; Zahrotunnimah; 2020).

Status pandemi atau epidemi global menandakan bahwa penyebaran Covid-19 berlangsung sangat cepat. Beberapa langkah cepat dilakukan oleh pemerintah agar virus corona ini tidak menular dengan cepat, seperti menerapkan work from home (WFH), Social Distancing, dan lain-lain (Tursina, 2020). Masyarakat juga diedukasi untuk menerapkan pola hidup sehat (Suprabowo, 2020) dengan mencuci tangan dengan sabun sesering mungkin, memakai masker ketika bepergian keluar rumah (Pratiwi, 2020), (Machendrawaty, Yuliani, Setiawan, \& Yuningsih, 2020), serta menjaga jarak (Mardiana \& Darmalaksana, 2020), (Masrul et al., 2020). Kondisi yang datang tiba-tiba ini membuat masyarakat tidak siap 
menghadapinya baik secara fisik ataupun psikis (Sabir \& Phil, 2016).

Diantara kondisi psikologis yang dialami oleh masyarakat adalah rasa anxiety apabila tertular (Fitria, 2020), (Hanifah, Yusuf Hasan, Nanda Noor, Tatang Agus, \& Muhammad, 2020). Menurut American Psychological Association (APA), kecemasan merupakan keadaan emosi yang muncul saat individu sedang stress, dan ditandai oleh perasaan tegang, pikirang yang mebuat individu merasa khawatir dan disertai respon fisik (jantung berdetak kencang, naiknya tekanan darah, dan lain sebagainya (Okazaki, 1997), (Beaudreau \& O'Hara, 2009). Kartini Kartono bahwa anxiety adalah bentuk ketidakberanian ditambah kerisauan terhadap hal-hal yang tidak jelas (Kartono \& Andari, 1989), (Annisa \& Ifdil, 2016). Senada dengan itu, Sarlito menjelaskan anxiety merupakan perasaan takut yang tidak jelas objeknya dan tidak jelas pula alasannya (Sarlito, 2012).

Anxiety ini juga dialami oleh para remaja (Gozali, Tjahyo, \& Vidyarini, 2018), karena usia remaja dapat dikatakan usia yang masih labil dalam menghadapi kondisi-kondisi yang tidak terduga (Tjukup, Putra, Yustiawan, \& Usfunan, 2020). Kondisi emosi remaja akan mudah terguncang seperti, anxiety yang berlebihan, ketakutan akan tertular virus ini dan sebagainya (Dani \& Mediantara, 2020).

\section{Metodologi}

Jenis penelitian adalah kuantitatif dengan menggunakan deskriptif analitik dengan pendekatan waktu cross sectional dimana pengukuran variable dependent serta variable independen diambil secara bersamaan ketika penelitian dilaksanakan, dan uji pada penelitian ini adalah uji analisis bivariate dengan uji chi square.

Populasi dalam penelitian ini adalah seluruh siswa di Pesantren Pancasila Kota Bengkulu. Sampel dalam penelitian ini menggunakan teknik simple random sampling, dengan total sampel sebanyak 32 siswa perempuan di MTS Pesantren Pancasila Kota Bengkulu.
Hasil dan Pembahasan Analisis Univariat

Tabel 1 Distribusi Tingkat Pengetahuan Responden terhadap Covid-19 pada Siswa di Pesantren Pancasila Kota Bengkulu.

\begin{tabular}{clcc}
\hline No. & Variabel & Frekuensi & Persentase (\%) \\
\hline 1 & $\begin{array}{l}\text { Pengetahuan } \\
\text { Kurang }\end{array}$ & 8 & 25,0 \\
\hline 2 & $\begin{array}{l}\text { Pengetahuan } \\
\text { cukup }\end{array}$ & 20 & 62,5 \\
\hline 3 & $\begin{array}{l}\text { Pengetahuan } \\
\text { baik }\end{array}$ & 4 & 12,5 \\
\hline & Total & 32 & 100 \\
\hline
\end{tabular}

Berdasarkan Tabel 1 diperoleh hasil bahwa dari 32 orang responden ditemukan sebanyak 20 orang $(62,5 \%)$ remaja yang berpengetahuan cukup terhadap covid-19.

Tabel 2 Distribusi Perilaku Responden terhadap Covid-19 pada Siswa di Pesantren Pancasila Kota Bengkulu.

\begin{tabular}{|c|c|c|c|}
\hline No. & Variabel & Frekuensi & Persentase (\%) \\
\hline 1 & $\begin{array}{l}\text { Perilaku } \\
\text { negative }\end{array}$ & 15 & 46,9 \\
\hline \multirow[t]{2}{*}{2} & $\begin{array}{l}\text { Perilaku } \\
\text { negative }\end{array}$ & 17 & 53,1 \\
\hline & Total & 32 & 100 \\
\hline $\begin{array}{l}\text { hasil } \\
\text { diten } \\
\text { rema } \\
\text { terha }\end{array}$ & $\begin{array}{l}\text { Berdasark } \\
\text { bahwa da } \\
\text { dkan sebar } \\
\text { yang me } \\
\text { ap Covid-1 }\end{array}$ & $\begin{array}{l}\text { Tabel } 5 . \\
32 \text { orang } \\
17 \text { ora } \\
\text { unyai per }\end{array}$ & $\begin{array}{r}\text { diperoleh } \\
\text { responden } \\
\text { g }(53,1 \%) \\
\text { aku positif }\end{array}$ \\
\hline
\end{tabular}

Tabel 3 Distribusi Tingkat Kecemasan Responden terhadap Covid-19 pada Siswa di Pesantren Pancasila Kota Bengkulu.

\begin{tabular}{clcc}
\hline No. & Variabel & Frekuensi & Persentase (\%) \\
\hline 1 & $\begin{array}{l}\text { Kecemasan } \\
\text { berat }\end{array}$ & 5 & 15,6 \\
\hline 2 & $\begin{array}{l}\text { Kecemasan } \\
\text { sedang }\end{array}$ & 4 & 12,5 \\
\hline 3 & $\begin{array}{l}\text { Kecemasan } \\
\text { Ringan }\end{array}$ & 6 & 18,8 \\
\hline 4 & $\begin{array}{l}\text { Tidak ada } \\
\text { kecemasan }\end{array}$ & 17 & 53,1 \\
\hline & Total & 32 & 100 \\
\hline
\end{tabular}

Berdasarkan Tabel 3 diperoleh hasil

bahwa dari 32 orang responden ditemukan 
sebanyak 17 orang $(53,1 \%)$ remaja yang mempunyai tingkat kecemasan tidak ada terhadap Covid-19.

\section{Analisis Bivariat}

Tabel 4 Hubungan Pengetahuan remaja terhadap Covid-19 dengan

Tingkat Kecemasan 19 pada Siswa di Pesantren Pancasila Kota Bengkulu.

\begin{tabular}{|c|c|c|c|c|c|c|c|c|c|}
\hline & \multicolumn{8}{|c|}{ Pengetahuan } & \multirow{3}{*}{$\mathrm{P}$} \\
\hline & \multicolumn{2}{|c|}{ Kurang } & \multicolumn{2}{|c|}{ Cukup } & \multicolumn{2}{|c|}{ Baik } & \multicolumn{2}{|c|}{ Total } & \\
\hline & $\mathrm{F}$ & $\%$ & $\mathrm{~F}$ & $\%$ & $\mathrm{~F}$ & $\%$ & $\mathrm{~F}$ & $\%$ & \\
\hline $\begin{array}{l}\text { Kecemasan } \\
\text { berat }\end{array}$ & 4 & 12,5 & 1 & 3,1 & 0 & 0 & 5 & 15,6 & \\
\hline $\begin{array}{l}\text { Kecemasan } \\
\text { sedang }\end{array}$ & 1 & 3,1 & 3 & 9,4 & 0 & 0 & 4 & 12,5 & 0,040 \\
\hline $\begin{array}{l}\text { Kecemasan } \\
\text { ringan }\end{array}$ & 1 & 3,1 & 5 & 15,6 & 0 & 0 & 6 & 18,8 & 044 \\
\hline $\begin{array}{l}\text { Tidak ada } \\
\text { kecemasan }\end{array}$ & 2 & 6,2 & 11 & 34,4 & 4 & 12,5 & 17 & 53,1 & \\
\hline
\end{tabular}

Berdasarkan tabel 4 diperoleh hasil nilai signifikasi ( $\mathrm{p}$ value) 0,044 lebih kecil dari (alpha) $=0,05$ sehingga disimpulkan ada hubungan antara pengetahuan dengan tingkat kecemasan pada Siswa di Pesantren Pancasila Kota Bengkulu.

\begin{tabular}{|c|c|c|c|c|c|c|c|}
\hline \multirow[t]{4}{*}{ Tabel } & \multicolumn{3}{|c|}{$\begin{array}{l}\text { Hubungan } \\
\text { terhadap } \\
\text { Tingkat K } \\
\text { Siswa di } \\
\text { Kota Beng }\end{array}$} & \multicolumn{2}{|c|}{$\begin{array}{l}\text { Perilaku } \\
\text { Covid-19 } \\
\text { ecemasan } \\
\text { esantren } \\
\text { ulu. }\end{array}$} & \multicolumn{2}{|c|}{$\begin{array}{r}\text { Remaja } \\
\text { dengan } \\
19 \text { pada } \\
\text { Pancasila }\end{array}$} \\
\hline & \multicolumn{6}{|c|}{ Perilaku } & \multirow{3}{*}{$\mathrm{P}$} \\
\hline & \multicolumn{2}{|c|}{ Negatif } & \multicolumn{2}{|c|}{ Positif } & \multicolumn{2}{|c|}{ Total } & \\
\hline & $\mathrm{F}$ & $\%$ & $\mathrm{~F}$ & $\%$ & $\mathrm{~F}$ & $\%$ & \\
\hline $\begin{array}{l}\text { Kecemasan } \\
\text { berat }\end{array}$ & 5 & 15,6 & 0 & 0 & 5 & 15,6 & \multirow{4}{*}{0,014} \\
\hline $\begin{array}{l}\text { Kecemasan } \\
\text { sedang }\end{array}$ & 3 & 9,4 & 1 & 3,1 & 4 & 12,5 & \\
\hline $\begin{array}{l}\text { Kecemasan } \\
\text { ringan }\end{array}$ & 3 & 9,4 & 3 & 9,4 & 6 & 18,8 & \\
\hline $\begin{array}{l}\text { Tidak ada } \\
\text { kecemasan }\end{array}$ & 4 & 12,5 & 13 & 40,6 & 17 & 53,1 & \\
\hline
\end{tabular}

Berdasarkan tabel 5 diperoleh hasil nilai signifikasi ( $\mathrm{p}$ value) 0,14 lebih kecil dari (alpha) $=0,05$ sehingga disimpulkan ada hubungan antara perilaku dengan tingkat kecemasan pada Siswa di Pesantren Pancasila Kota Bengkulu.

Tingkat pengetahuan remaja tentang Covid-19 menunjukkan sebagian besar adalah cukup sebanyak 20 responden $(62,5 \%)$. Kondisi tersebut antara lain dipengaruhi oleh beberapa faktor yaitu ketersediaan informasi tentang covid-19.

Pengetahuan adalah suatu hasil dari rasa ingin tahu melalui proses sensoris, terutama pada mata dan telinga terhadap objek tertentu. Pengetahuan juga merupakan domain terpenting dalam terbentuknya perilaku (Donsu, 2017). Pengetahuan yang yang harus dimiliki oleh masyarakat dengan baik dan benar saat ini dalam mengurangi penyebaran atau penularan covid-19 adalah mencakup pengetahuan tentang pengertian, penyebab, tanda dan gejala serta cara penularan dan pencegahan, dan pengobatan Covid-19 (Media, 2012).

Hasil penelitian penelitian menyatakan bahwa tingkat anxiety remaja $15,6 \%$ berada pada kategori tinggi. Hal ini kemungkinan besar disebabkan karena kurangnya informasi yang diperoleh remaja terkait dengan pandemic covid-19 ini (Purwanto et al., 2020). Yang ada pada pikiran remaja adalah virus corona sangat berbahaya (Zaharah, Kirilova, \& Windarti, 2020), yang apabila seseorang terinfeksi virus ini sulit untuk sembuh (Putri, 2020), dan kebanyakan meninggal.

Beberapa faktor yang menyebabkan anxiety pada masa pandemic COVID19 adalah kurangnya informasi mengenai kondisi ini, pemberitaan yang terlalu heboh di media masa ataupun media social (Aulia, 2018), kurangnya membaca literasi terkait dengan penyebaran dan mengantisipasi penularan corona virus.

Anxiety yang dialami remaja ini akan berdampak kepada; 1) Kurang tidu, anxiety dapat menyebabkan insomnia dan masalah tidur lainnya (Sohat, Bidjuni, \& Kallo, 2014). Semakin sedikit tidur maka semakin besar tingkat anxiety. Untuk mengatasi kurang tidur dapat dilakukan dengan fokus pada cara-cara untuk meningkatan kualitas tidur, dengan meningkatnya kualitas tidur maka dapat mengurangi anxiety.

Pertahankanlah waktu tidur yang konsisten, batasi konsumsi kopi dan alkohol, 
matikan alarm, olahraga, dan berjemur pada paparan sinar matahari setiap hari. Hal lain yang dapat dilakukan adalah menjaga kamar tidur tetap sejuk, gelap dan tenang, serta menjauhi gadget agar lebih cepat tidur; 2) Kesulitan untuk fokus, COVID19 telah mengancam kesehatan fisik dan psikis, dan cara hidup sehari-hari.

Secara tidak sengaja, setiap hari terus mendengar berbagai berita dan kemudian memikirkan cara-cara untuk melindungi diri dari virus. Masalahnya adalah, selama di rumah juga harus tetap fokus untuk belajar. Akibat pemberitaan COVID19, pikiran menjadi tidak fokus dan sulit berkonsentrasi pada pelajaran (Hanifah, et al., 2020). Cara untuk meningkatkan konsentrasi pada masa pandemic ini adalah dengan mengurutkan apa yang mesti dilakukan, serta jangan lupa juga untuk istirahat yang cukup; 3) Sering lupa, Alexandra Parpura, ahli gerontologi dan pendiri Aging Perspectives di Chevy Chase menjelaskan bahwa anxiety dapat mempengaruhi memori. Apa pun yang merilekskan tubuh akan membantu ingatan, karena relaksasi melibatkan sistem saraf parasimpatis.

Kegiatan relaksasi yang baik seperti olahragajuga dapat merelaksasi ingatan. Melakukan permainan yang mengasah kemampuan untuk fokus seperti teka-teki silang, Sudoku, membuat kerajinan tangan, bermain video games, atau bermain alat musik juga dapat membantu untuk mengurangi lupa; 4) Meningkatnya iritabilitas dan mudah marah, anxiety dapat merubah emosi remaja seperti mudah marah. Anxiety yang dialami tiap orang berbedabeda, tentu saja hal ini berkontribusi terhadap iritabilitas dan kemarahan.

Penelitian menunjukkan bahwa anxiety juga dapat memicu emosi ini (Hanifah, et al., 2020). Kondisi anxiety yang dialami remaja pada masa pandemic ini tentu tidak bisa dibiarkan begitu saja (Harirah \& Rizaldi, 2020). Untuk mengatasi anxiety pada remaja ini peran orangtua sangat dibutuhkan (Fuad \& Budiyono, 2012), diantaranya selalu mendampingi, memotivasi, memberikan pengetahuan tentang COVID-19 ini. Selaku konselor atau guru bimbingan dan konseling ada beberapa hal yang dapat dilakukan untuk membantu remaja mengatasi anxiety adalah dengan memberikan pelayanan seperti layanan konseling individual, bimbingan dan konseling kelompok. Berbagai pendekatan konseling dapat diterapkan dalam kegiatan ini. Berdasarkan beberapa penelitian menyatakan menggunakan pendekan Cognitive Behavioral Therapy (CBT) lebih efektif untuk mengatasi kecemasan (Apriliana, Suranata, \& Dharsana, 2019), dibandingkan pendekatan yang lain.

\section{Simpulan}

Ada hubungan pengetahuan dan perilaku remaja terhadap Covid-19 dengan tingkat kecemasan pada siswa di Pesantren Pancasila Kota Bengkulu.

\section{Daftar Pustaka}

Arshad Ali, S., Baloch, M., Ahmed, N., Arshad Ali, A., \& Iqbal, A. (2020). The outbreak of Coronavirus Disease 2019 (COVID-19)_An emerging global health threat. Journal of Infection and Public Health, 13(4), 644646.

https://doi.org/10.1016/j.jiph.2020.02.0.33

Badrya, L. Perbedaan Tingkat Kecemasan antara Mahasiswa Kedokteran Laki-laki dan Perempuan Angkatan 2011 FKIK UIN Syarif Hidayatullah Jakarta dalam Menghadapi Ujian OSCE. Jakarta. 2014.

Kementerian Kesehatan RI. 2010. Riset Kesehatan Dasar (Riskesdas). Jakarta:Kemenkes RI.

Maureen (2020) PCR Swab \& Rapid test: Apakah Bedanya dan Bagaimana Prosedurnya? Diakses online dari https://www.emc.id/id/care-plus/pcrswabrapid-test-apakah-bedanya-danbagaimanaprosedurnya pada tanggal 24 Agustus 2020

Notoatmodjo S. (2010). Kesehatan masyarakatilmu dan seni. Jakarta: Rineka Cipta

Purnamasari, Ika; Raharyani, A. E. (2020). Tingkat Pengetahuan Dan Perilaku Masyarakat Kabupaten Wonosobo Tentang Covid-19. Jurnal Ilmiah Kesehatan, 10(1), 33-42. Retrieved from https://ojs.unsiq.ac.id/index.php/jik/artic le/view/1311/783

Sari, D.P, dan Atiqoh, N.S (2020) Hubungan Antara Pengetahuan Masyarakat Dengan Kepatuhan Penggunaan Masker Sebagai Upaya Pencegahan Penyakit Covid-19 Di Ngoronggah. Rekam Medis dan Informasi 
Kesehatan, Fakultas Kesehatan, Universitas Duta Bangsa

Syafrida, S. dan Hartati. R., (2020). Bersama Melawan Virus Covid 19 di Indonesia. Jurnal Sosial \& Budaya Syar-i. 7(6)

World Health Organization (2020) Anjuran Mengenai Pemakaian Masker Dalam Konteks Covid-19. Diakses online dari https://www.who.int/docs/defaultsource/se aro/indonesia/covid19/anjura n-mengenaipenggunaan-maskerdalam-kontekscovid19.pdf?sfvrsn=8a209b04_2 pada tanggal 24 Agustus 2020

Yanti, dkk (2020) Community Knowledge, Attitudes, And Behavior Towards Social Distancing Policy As Prevention Transmission Of Covid-19 In Indonesia, JAKI (Jurnal Administrasi Kesehatan Indonesia) Volume 8 (2020)

Yuliana (2020) Corona virus diseases (Covid-19); Sebuah tinjauan literatur. Welness and Healthy Magazine vol. 2(1)

Yunus, N.R dan Reski, A. (2020). Kebijakan Pemberlakuan Lockdwon Sebagai Antisipasi Penyebaran Corona Virus Covid-19. Journal Sosial dan Budaya SyarI. Vol. 7(3)

Zahrotunnimah (2020) Langkah Taktis Pemerintah Daerah Dalam Pencegahan Penyebaran Virus Corona Covid-19 di Indonesia. Jurnal Sosial \& Budaya Syari. 7(3). 